\title{
地震被災 $\mathrm{RC}$ 造建物の観測と解析に基づく応答推定に関する基礎研究 FEASIBILITY STUDY ON SEISMIC RESPONSE ESTIMATION OF DAMAGED RC BUILDINGS BASED ON OBSERVATION DATA AND NUMERICAL ANALYSES
}

\author{
崔琥*, 真田靖士**, 渡邊泰宏***, 朝長拓也*** \\ Ho CHOI, Yasushi SANADA, Yasuhiro WATANABE \\ and Takuya TOMONAGA
}

\begin{abstract}
The objective of this research is to analytically estimate seismic responses, in particular maximum drifts of earthquake-damaged RC buildings. A predominant period obtained by ambient vibration measurements and a residual seismic capacity ratio index $R$ based on damage classes of columns were applied to evaluate a maximum drift of an example of earthquake-damaged buildings. As a result, the proposed method based on the $R$-index approximately reproduced damage to columns in the most severely damaged story, while the other method by the predominant period overestimated. Characteristics and scope of both methods were also investigated through the application above.
\end{abstract}

Keywords : Ambient vibration measurement, Pushover analysis, Modal analysis, Maximum response, Damage class, Residual seismic capacity ratio index

微動測定, 静的増分解析, 固有值解析, 最大応答変形, 損傷度, 而震性能残存率

\section{1. はじめに}

途上国で地震災害が発生すると先進国より遥かに甚大な被害を伴 う。一般に, 地震災害は人的, 物的犠牲と引き換えに今後の地震防災 に貴重な知見を残寸が，途上国では研究環境が不十分なため先進国よ りも得られる知見が少ないのが現状である。これは地震観測網が未整 備であり, ローカルな地震力が高精度で得られない問題などに起因す る。数年来, 筆者らはインドネシアの建物被害の学会調查団に参加し, 後世に残寸知見の収集に努めたが例えば 1)，2)，上記の問題により地震被 害の定量的な分析には限界があったのも事実である。

そこで本研究では, 耐震性能が明らかなエンジニアド RC 建物の地 震被害調查により得られた損傷状況から, 逆に建物に入力された地震 力 (主に強度型の建物の場合) や応答変形 (主に鞋性型の建物の場合) を同定する手法を提案・検証することを主目的とする。本研究と趣旨 をともにする既往の研究例として文献 3）が挙げられる。この研究で は強震記録および建物の被災度から地震動強さを推定する手法につ いて統計的に検討されている。一方，本研究は被災建物の損傷状況か ら当該建物に作用した地震力や建物の忘答変形を評価寸ることに主 眼を置いており, 既往の研究とはアウトプットとして期待する指標や そこへ至るアプローチが異なる。他方，近年では地震力を受けた RC 部材の損傷を評価する研究も進められ例党壮 4), 被災度区分判定基準 5 ) に代表される建物の地震後の性能を評価する枠組も整備されている。 このように建物の性能評価の基礎資料が充実しつつある学術的な動
向を背景として, 本研究では地震動入力が不明な被苂建物の損傷に関 する各種データに基づいて, 建物の地震応答を推定する手法の実現を 試みる。

本論文ではその第一段階として, 勒性型の建物が地震により経験し た最大応答変形を推定する手法について検討する。微動測定に基づく 卓越周期と, 部材の損傷の二通りを指標として建物の最大応答変形を 推定する手法を提案する。筆者らが過去に地震被害調查したインドネ シアの RC 建物を対象に, 二通りの提案手法を適用し地震時の最大経 験変形を推定し，各手法の固有の特性を分析するとともにその妥当性 について検討する。

\section{2. 研究対象とする地震被害建物}

本節では今回の地震の概要, 研究対象建物の概要や被害状況につい て述べる。

\section{1 地震の概要}

2009 年 9 月 30 日 17 時 16 分（現地時間）にインドネシア・スマト ラ島西部のインド洋沖（南緯 0.72 度, 東経 99.86 度, 深さ $81 \mathrm{~km}$ ）を 震源とするマグニチュード $\left(\mathrm{M}_{\mathrm{w}}\right) 7.5$ の地震が発生した ${ }^{6}$ 。ここの地震 により, 震源から東南東方向に約 $60 \mathrm{~km}$ に位置する Padang 市において 比較的規模が大きい RC 建物に数多く被害が発生した。

文献 7)に今回の地震で唯一計測された加速度記録 $(\mathrm{PGA} \fallingdotseq 0.3 \mathrm{~g})$ と
$*$ 東京大学生产技術研究所 助教 · 博士 (工学)

** 大阪大学大学院工学研究科 准教授 $\cdot$ 博士 (工学

*** 豊橋技術科学大学大学院工学研究科 大学院生
Research Assoc., Institute of Industrial Science, The University of Tokyo, Ph. D.

Assoc. Prof., Graduate School of Engineering, Osaka University, Dr. Eng.

Graduate Student, Graduated School of Engineering, Toyohashi University of Technology 


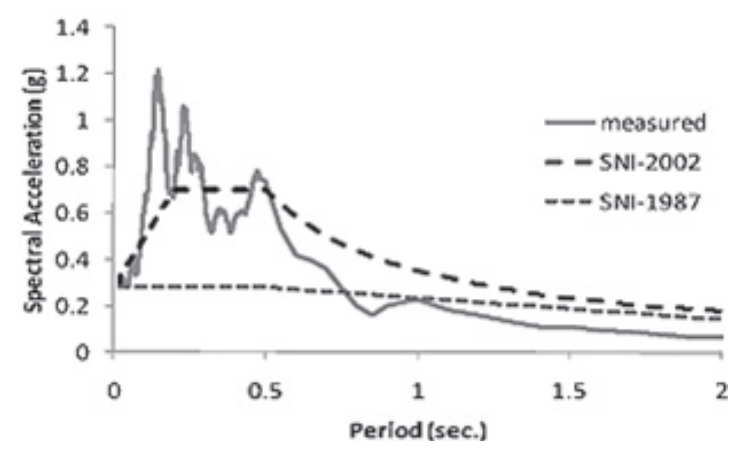

図 1 加速度応答スペクトルおよび設計用スペクトル

（文献 7）より抜粋）

加速度応答スペクトルが紹介されている。図 1 に文献 7）より抜粋し た加速度応答スペクトルおよびインドネシアの設計用スペクトル

（SNI-1987，SNI-2002 はそれぞれ 1987 年，2002 年設計基準值）を示 す。計測場所は海岸から東方向に $12 \mathrm{~km}$ の岩盤上に位置する Andalas 大学である。図 1 より, 加速度応答スペクトルは 0.15 秒付近で $1.2 \mathrm{~g}$ と，2002 年度に改訂された設計用加速度スペクトル（SNI-2002）を遥 かに超えている。一方， RC 建物の被害が大きかった Padang 市内は海 岸沿いの軟弱地盤であるため, 卓越周期は図 1 の結果より長くなると 報告されている ${ }^{7)}$ 。

筆者らは 2 回にわたって現地調査を実施し（1 回目：2009 年 12 月 13 日〜20日，2 回目：2011 年 8 月 26 日〜29日)，典型的な RC 造 5 階建て建物について詳細な被害状況を調べるとともに, 微動測定記録 を取得した。以下では，研究対象建物およびその被害概要についてま とめる。

\section{2 研究対象建物とその被害状況 ${ }^{2)}$}

研究対象建物である BPKP（ Badan Pengawasan Keuangan Dan Pebangunan) は Padang 市内中心部に所在する 2003 年に建設された RC 造 5 階建て公共建物（会計検査院）である。写真 1 に被災前後の建物 の外観を, 図 2 に被害が相対的に大きかった 2 階および 3 階の平面図 を柱の損傷度 ${ }^{5)}$ (黒色：梁間（EW）方向，灰色：桁行（NS）方向） と併せて示す。建物のスパン長さは桁行方向および梁間方向ともに $6 \mathrm{~m}$ (図 2 参照), 柱の内法高さは $3.5 \mathrm{~m}$ である。表 1 に代表的な柱断面 リストを示す。その他，スラブ厚さは $120 \mathrm{~mm}$ ，シュミットハンマー試 験に基づくコンクリートの圧縮強度の平均值は $25.2 \mathrm{~N} / \mathrm{mm}^{2}$ (この值は 経年劣化を考慮し低減係数 $0.6\left(1000\right.$ 日以上)を乗じたものである $\left.{ }^{8)}\right)$, 主筋およびせん断補強筋の種類・規格降伏点強度はそれぞれ異形鉄 筋・395N/mm² および丸鋼・235N/mm²である。壁はすべて非構造壁で あり，無補強のレンガ造である。図 2 に示すように, レンガ壁は桁行 (NS) 方向の壁量が相対的に多く, 梁間 $(\mathrm{EW})$ 方向では少なかった。 以下に, 各階の損傷状況を要約する。

1 階は構面(2), (4)間がピロティとなっているが, RC 主体架構の損 傷は小さかった。ただし，(C)一(1)柱の脚部でジャンカが見られ，その 周辺の主筋が露出していた。2階の損傷は 1 階よりもやや大きく, 図 2（a）に示すように巨)一(4)柱はカバーコンクリートの一部剥落（損傷 度 II)，(E)一(5)およびF-(4)柱の頭部では主筋の露出が見られた（損 傷度 IV)。その他，数本の柱で柱頭および接合部に曲げひび割れが観 察された。柱の損傷度は西側構面の方が大きかった。3 階の損傷は全

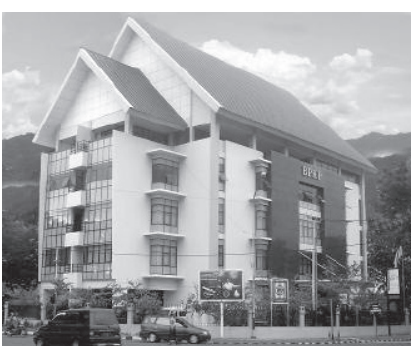

(a) 被災前

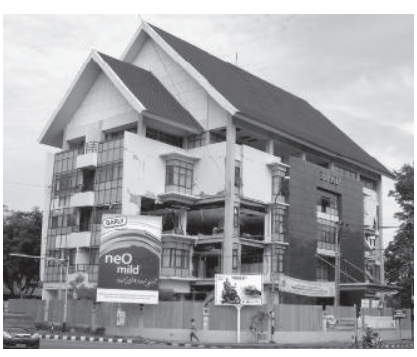

（b）被災後
写真 1 調査対象建物の被苂前後の外観

0 - V: 柱の梁間 (EW) 方向, 0 - V: 柱の桁行 (NS) 方向
(A)
(B) (C)
(D)
(E) (F)
(G)
(H)

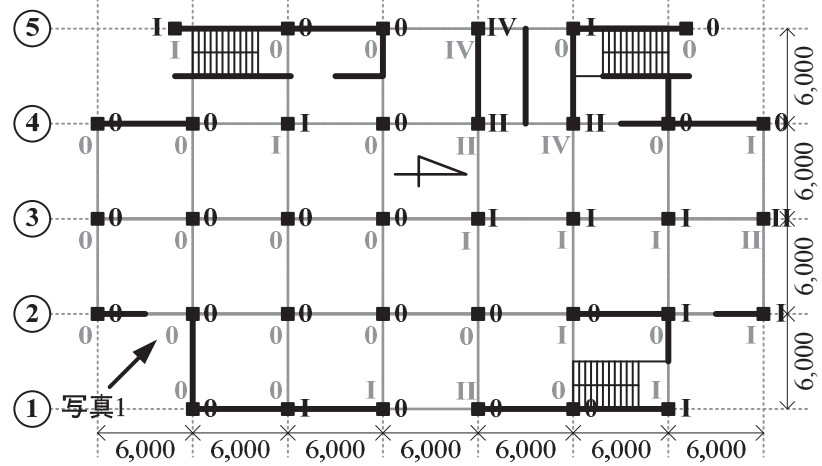

(a) 2 階
(A)
(B) (C)
(D) (E)
(F) (G)
(1)

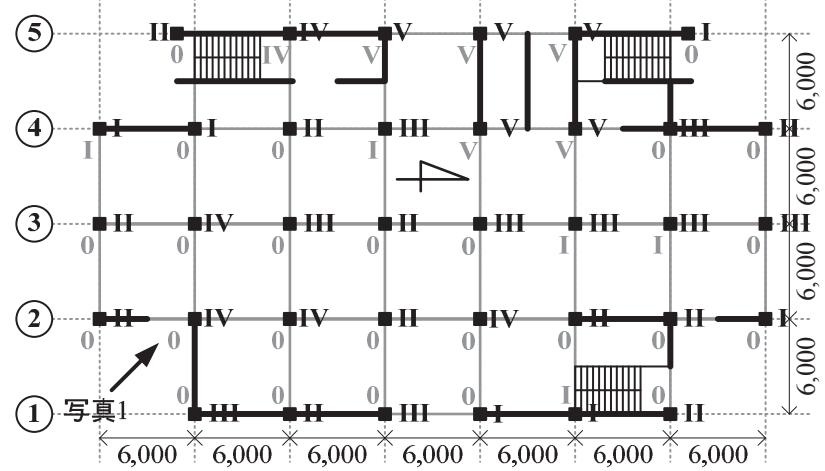

(b) 3 階

図 2 平面図および損傷度判定結果（単位：mm)

表 1 柱断面リスト

\begin{tabular}{c|c|c}
\hline & 1 階および 2 階 & 3 階〜5 階 \\
\hline 断面寸法 $(\mathrm{mm})$ & $550 \times 550$ & $450 \times 450$ \\
\hline 主筋 & $16-\mathrm{D} 19$ & $12-\mathrm{D} 19$ \\
\hline せん断補強筋/フック & \multicolumn{2}{|c}{$\phi 9 @ 150 / 90^{\circ}$} \\
\hline
\end{tabular}

層で最も大きく, 特に構面(4)よび構面(5)の数箇所の柱頭部において 主筋の座屈, せん断補強筋の破断が観察された（損傷度 V, 写真 2 )。 また, 構面(2)および構面(3)の柱頭, 柱脚で主筋が露出していた（損傷 度 IV，写真 3)。2 階と同様に西側の損傷が顕著であった。4 階ではB 構面の柱および $(\mathrm{P}$ 一(4)柱でカバーコンクリートが一部剥落したが，そ の他の柱に大きな損傷は見られなかった。5 階では柱の被害はほとん 


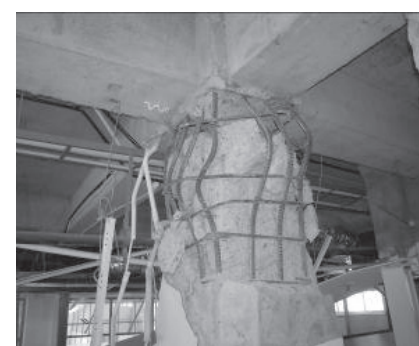

写真 2 損傷度 V の柱

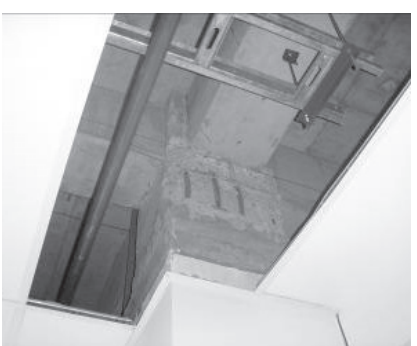

写真 3 損傷度 IV の柱
表 2 被災度区分判定結果（単位：\%)

\begin{tabular}{c|c|c||c|c}
\hline 階数 & 桁行の $R$ 值 & 桁行の被災度 & 梁間の $R$ 值 & 梁間の被災度 \\
\hline $1 \mathrm{~F}$ & 98.8 & 軽微 & 94.5 & 小破 \\
\hline $2 \mathrm{~F}$ & 85.9 & 小破 & 89.4 & 小破 \\
\hline $3 \mathrm{~F}$ & 85.0 & 小破 & 54.1 & 大破 \\
\hline $4 \mathrm{~F}$ & 100.0 & 無被害 & 96.7 & 軽微 \\
\hline $5 \mathrm{~F}$ & 98.6 & 軽微 & 99.3 & 軽微 \\
\hline
\end{tabular}

ど見られず, (D)-(5)柱で損傷度 II の曲げせん断ひび割れが生じた程度 であった。

文献 5)に従って実施した被災度区分判定の結果を表 2 に示す。3 階 梁間方向のみ大破，それ以外は小破以下であり，実際の損傷状況と整 合した。

\section{3. 被災建物の振動特性評価}

研究対象建物の詳細調査では常時微動計測を実施した。本節では現 地計測の概要を示すとともに, 本研究で提案する地震被災建物の最大 応答変形の一推定手法に必要な建物の卓越周期の評価結果を示寸。ま た，建物高さ方向のモード形状を実際の損傷状況と比較する。

\section{1 測定方法}

測定機器に収録器（物探サービス株式会社製 GEODAS-15-HS）およ びピックアップ（物探サービス株式会社製 ムービングコイル型速度 計 CR4.5-2 型）を使用し，サンプリング周波数を $100 \mathrm{~Hz}$ ，収録時間を 300 秒間として常時微動計測を実施した。全 7 ケースの計測ケースの 内, 本研究の検討に用いた 2 ケースの測定位置を図 3 に示す。また, 測定時の様子を写真 4 に示寸。

\section{2 測定結果}

\section{（1）建物の卓越周期}

図 3 に示寸 2 つの計測ケースにおいて, バンド幅 $0.5 \mathrm{~Hz}$ の Parzen Window を用いて平滑化し求めた, 1 階の常時微動水平成分のフーリ エスペクトルに対する各階の同スペクトル比（伝達関数）を図 4 に示 す。桁行 (NS) 方向について, 1 次固有周期は計測ケース 1 では 0.60 秒，計測ケース 2 では 0.89 秒， 2 次固有周期は計測ケース 1 では 0.17 秒, 計測ケース 2 では 0.24 秒と, 構面内レンガ壁量が多い構面(5)（計 測ケース 1）の固有周期がやや短い結果であった。一方，梁間（EW） 方向については 1 次および 2 次固有周期は両計測ケースともにそれぞ れ 1.14 秒および 0.30 秒であった。これらの結果から，レンガ壁が少 なく柱の損傷が大きい梁間方向の周期が，桁行方向より長く，図 2 や 表 2 の結果と整合することを確認した。

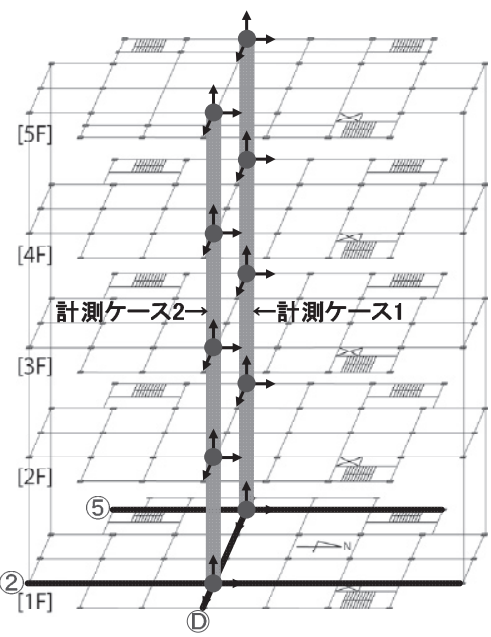

図 3 本研究で用いた計測ケース
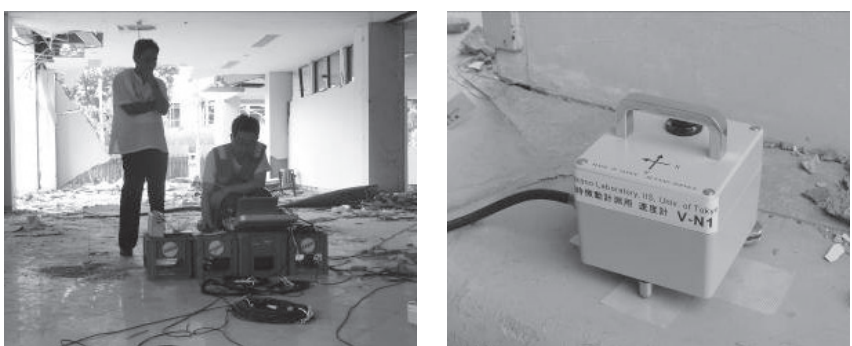

写真 4 測定の様子

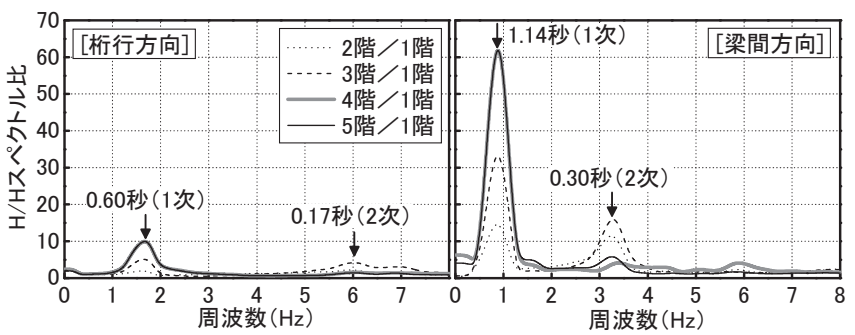

(a) 計測ケース 1 (D)-(5))

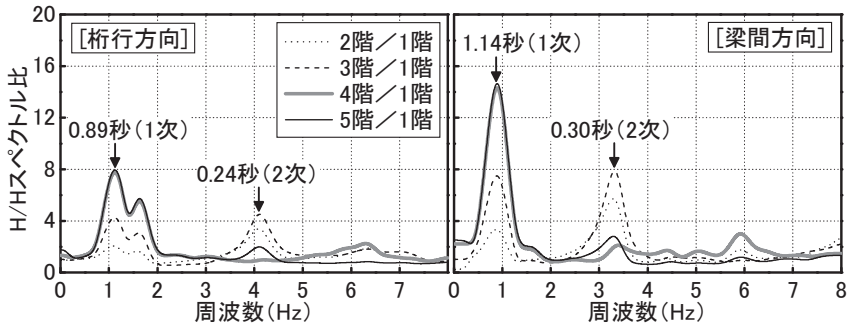

(b) 計測ケース 2（D)-(2)

図 41 階に対する各階のスペクトル比および固有周期

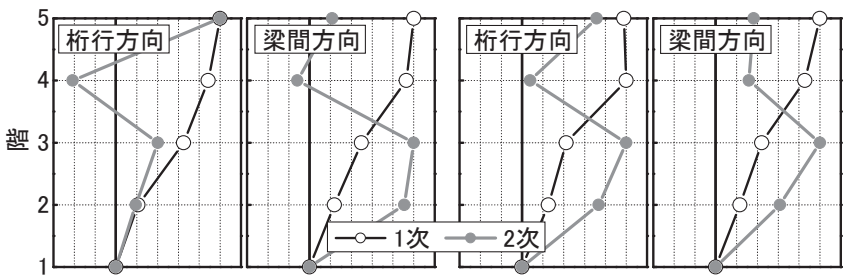

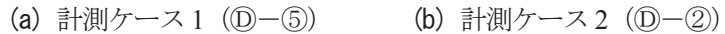

図 5 建物高さ方向のモード形状 


\section{（2）建物高さ方向のモード形状}

建物高さ方向の振動モードの推定には, 図 4 で示した振幅に関する 情報に加えて, 位相差の情報が必要である。本研究では以下の仮定に 基づき振動モードを推定した。

フーリエ振幅スペクトルで各固有周波数における振幅スペクト ル值が最大となる測定点を基準点とし（本研究では図 4 (a) および （b）より， 1 次モードでは 5 階 $/ 1$ 階を， 2 次モードでは 3 階 $/ 1$ 階を基準点とした), 同じ周波数におけるその他の測定点と基準点 との位相差をフーリエ位相スペクトル值の差 $\Delta \theta(-\pi<\theta<\pi)$ とし て求めた。この時, 振幅スペクトル值に位相スペクトル值の差の余 弦 $\cos \Delta \theta$ を乗じたものがモード形状を模擬するものと仮定して振動 モードを推定した。以上の推定手法より求めた両計測ケースにおけ る桁行方向および梁間方向のモード形状を図 5 に示寸。同図より, いずれの結果も同様のモード形状を示しており, 特に 2 次モード形 状は 3 階の柱頭部の損傷が大きかった実際の被害実態をよく表し ている。

\section{4. 対象建物の地震応答の推定}

本節では常時微動計測より得られた被災後の建物の卓越周期と文 献 5)で定義される耐震性能残存率 $R$ に基づいて, 研究対象建物の最大 経験変形を解析的に推定する。以下に，推定で併用寸る静的増分解析 における仮定条件や両手法における推定フローおよびその推定結果 について詳細に述べる。

\section{1 静的増分解析}

\section{(1) 解析仮定}

本研究では, 研究対象建物の被害が相対的に大きかった梁間方向 (地震力が卓越したと判断される主軸方向 ${ }^{2)}$ ) を対象に静的増分解析 を行う。また，最大被災層 3 階梁間方向の柱の損傷度はおよそ構面(1) <構面(2)～(4)<構面(5)であった結果から（図2（b)），構面(1)から構面 (5)（東から西）の方向の地震動入力が卓越し, 外側構面(1) と (5)の柱が 変動軸力により前者は引張力, 後者は圧縮力を受けたと推察し, 解析 では構面(1)から構面(5)の方向に載荷する計画とした。解析における仮 定は以下の通りである。

(1) 各部材は剛域を有する線材に置換した。剛域は各部材のフェイ スから $D / 4 （ D$ : 各部材のせい）接合部内位置までとした。

(2) 基礎は固定，床は剛床と仮定した。

(3) 各柱の軸力算定には, 構造躯体の重量に加え, 積載荷重および 非構造の無補強レンガ壁の重量を考慮した。ここで，積載荷重 はインドネシアの基準（事務室，SNI 03-1727-1989-F）を準用し $2.45 \mathrm{kN} / \mathrm{m}^{2}$ とした。以上により精算した単位面積当たりの重量は, 1 階は $10.2 \mathrm{kN} / \mathrm{m}^{2}, 2$ 階および 3 階は $10.0 \mathrm{kN} / \mathrm{m}^{2}, 4$ 階は $10.9 \mathrm{kN} / \mathrm{m}^{2}$, 5 階は $8.8 \mathrm{kN} / \mathrm{m}^{2}$ であり, 日本 $\left(12 \mathrm{kN} / \mathrm{m}^{29)}\right)$ に比べると約 73〜91\% 程度である。また，柱の曲げ終局強度の算定時の軸力は，解析 より得られた降伏変形角付近 $(0.67 \%)$ での変動軸力分を考慮し た（表４の（）の中の值)。

(4) RC 梁は被害が軽微であり,また配筋詳細が不明であったため, 本稿では弾性と仮定した。ただし，文献 2) より本建物の一部 の梁には軽微な曲げひび割れが観察された点を補足する。無開
口無補強レンガ壁が存在する構面( $\mathrm{E}$ の(4)一(5), 構面 $\mathrm{P}$ の(4)-(5) および構面Bの(1)-(2)（図 2 参照）においては，レンガ壁が梁 の変形を拘束するものと仮定し，上下の梁を剛として解析を行 った。なお，特に構面(B)の (1)一(2)の壁は地震後に複数層にわた り面外方向に崩落していた点を補足する（写真 1 )。

(5) $\mathrm{RC}$ 柱は両材端の弾塑性曲げバネと, 弾性せん断バネおよび弾性 軸バネを有する線材に置換した。また，曲げバネの復元力特性 は Takeda model ${ }^{10)}$ (除荷剛性低減指数 $\alpha=0.4$, これは後述の図 9 の実験結果に基づいて定めた值である）とし，曲げひび割れ強 度 $M_{C}$ および曲げ終局強度 $M_{U}$ は文献 11)による值を，降伏点剛 性低下率 $\alpha_{y}$ は文献 12)による值を, 降伏後の剛性は初期剛性の 1/1000をそれぞれ用いた。

(6) 建物梁間方向の弾性時の固有值解析による 1 次モードの等価質 量比は $82.5 \%$, 図 5 （a）のモード形状から求めた建物が損傷を 受けた後の 1 次モードの等価質量比は $78.5 \%$ であった。損傷の 有無に関わらず 1 次モードの等価質量比は概衫 $80 \%$ と支配的で あることから，本稿では外力分布を弾性 1 次モード比例分布と した。

また，解析の際に用いた材料強度や， 3 階柱の水平耐力および柱の 曲げ終局強度の算定に用いた変動軸力を考慮した各柱の軸力を表 3 お よび表 4 にそれぞれ示す。

\section{(2) 解析結果}

前項で定めた解析仮定に基づき静的増分解析を行った。その結果 から得られた研究対象建物の層せん断力一層間変形角の関係を建物 高さ方向の層間変形角分布の推移と併せて図 6 に示寸。同図より, 3 階の層間変形角が約 $1.0 \%$ を超えた後に変形が 3 階に集中しており, 図 2 (b) および表 2 に示した実際の被害状況と整合する結果が得ら れた。

表 3 解析に用いた材料強度

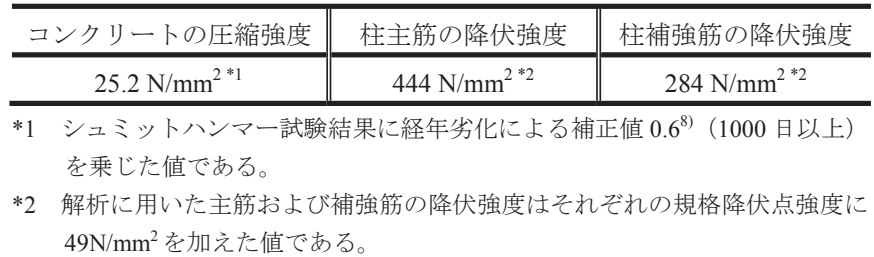

表 43 階柱の水平耐力および耐力計算時の軸力（単位 : $\mathrm{kN}$ )

\begin{tabular}{c|c|c|c|c|c|c|c|c}
\hline 構面 & $\mathrm{A}$ & $\mathrm{B}$ & $\mathrm{C}$ & $\mathrm{D}$ & $\mathrm{E}$ & $\mathrm{F}$ & $\mathrm{G}$ & $\mathrm{H}$ \\
\hline 5 & - & $\begin{array}{c}174 \\
(619)\end{array}$ & $\begin{array}{c}217 \\
(1,132)\end{array}$ & $\begin{array}{c}179 \\
(677)\end{array}$ & $\begin{array}{c}194 \\
(842)\end{array}$ & $\begin{array}{c}204 \\
(958)\end{array}$ & $\begin{array}{c}176 \\
(641)\end{array}$ & - \\
\hline 5 & 135 & 177 & 185 & 188 & 205 & 205 & 186 & 135 \\
& $(258)$ & $(652)$ & $(739)$ & $(769)$ & $(972)$ & $(972)$ & $(750)$ & $(258)$ \\
\hline 3 & 153 & 190 & 185 & 185 & 190 & 185 & 190 & 153 \\
& $(418)$ & $(788)$ & $(739)$ & $(739)$ & $(788)$ & $(739)$ & $(788)$ & $(418)$ \\
\hline 2 & 135 & 175 & 186 & 186 & 187 & 200 & 182 & 135 \\
& $(258)$ & $(628)$ & $(751)$ & $(751)$ & $(757)$ & $(910)$ & $(701)$ & $(258)$ \\
\hline 1 & - & 100 & 133 & 133 & 127 & 134 & 98 & - \\
\hline & & $(-42)$ & $(237)$ & $(237)$ & $(186)$ & $(245)$ & $(-54)$ & \\
\hline
\end{tabular}

*（）：柱の曲げ終局強度の算定に用いた変動軸力を考慮した各柱の軸力 


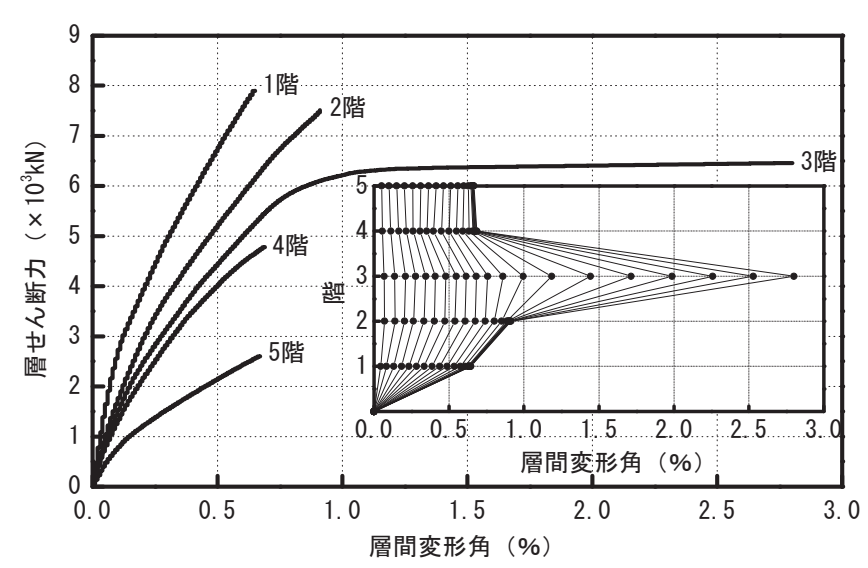

図 6 層せん断力一層間変形角の関係および層間変形角の推移

\section{2 微動測定による卓越周期に基づく応答変形推定手法}

本項では, 建物の最大応答变形の推定手法の一つとして, 解析から 得られる除荷時固有周期が微動測定に基づく建物の被災後の卓越周 期と一致する時の除荷点変形を評価し, これを建物が地震時に経験し た最大応答変形と見なす手法を提示する。併せて, 推定された最大応 答変形における最大被災層である 3 階の梁間方向における各部材の損 傷度について, 解析結果と実被害を比較し, 本推定手法の妥当性を検 討する。

\section{(1) 推定フロー \\ 本推定手法のフロー図を図 7 に示寸。}

(1) 対象建物に対して静的増分解析を行う（図７の(1))。

(2) 各ステップ $j$ で除荷を行い, 各層の除荷時剛性 $K_{u}^{i}(i$ : 層番号) を算定する（図７の(2)）。

(3) 上記(2)より得られる各層の除荷時剛性 $K_{u}{ }^{i}$ を与えた 5 質点系モデ ルの固有值解析より, 各ステップ $j$ での建物の除荷時周期 $T_{j}$ を 算定する (図 7 の(3)。

(4) $T_{j}=T_{T}$ (目標卓越周期, 図 4 より梁間方向の $T_{T}=1.14$ 秒) を満 足するまで上記の (1)〜 (3)を反復計算する (図 7 の (4))。

(5) $T_{j}=T_{T}$ の時の除荷点変形を本研究対象建物の最大経験変形と見 なす。

ここで, 建物の除荷時周期 $T_{j}$ は建物が最大応答変形を経験した直 後の除荷過程における周期に相当寸る（図 8 の（a)）。一方，目標卓 越周期 $T_{T}$ は常時微動計測から求まる卓越周期であり, 地震終了後の 残留変形付近での 1 次固有周期である (図 8 の (b))。本研究では, 文献 13)および 14)から対象建物の 3 階の柱と構造特性が近似する柱 で, 大振幅後の小振幅載荷された 3 体の実験デー夕を抽出し, 両者 の対応を検討した。表 5 および図 9 に抽出した試験体および実験結 果の一例を示寸。図 10 に全試験体の大振幅直後の除荷時剛性（図 8 の（a）より除荷開始点から終了点を結ぶ割線剛性）と，その後の載 荷過程における最大経験変形を超過しない小振幅繰り返し載荷時の 割線剛性（図 8 の（b）より正負の最大応答点を結ぶ割線剛性）を比 較する。図 10 より, 大振幅に対する小振幅の割線剛性の比の平均 $\mu$ は 0.93 と, 大振幅時の割線剛性より小振幅時の割線剛性が全体的に

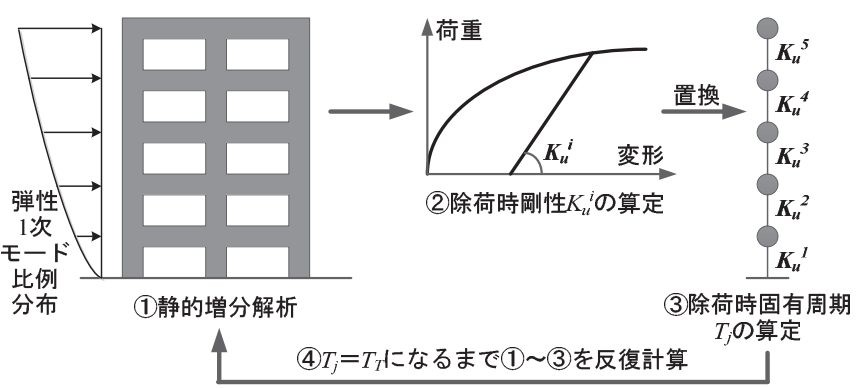

図 7 卓越周期に基づく最大応答変形の推定フロー

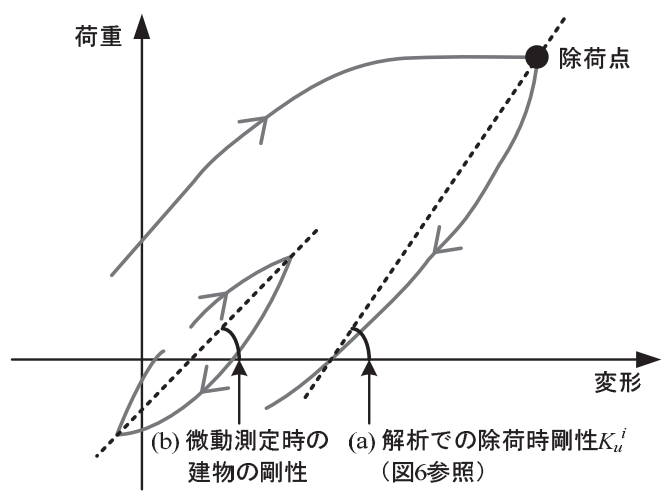

図 8 大振幅とその後の小振幅での割線剛性の概念図

表 5 対象建物の 3 階柱と文献 13)および 14)から抽出した柱の諸元

\begin{tabular}{|c|c|c|c|c|c|}
\hline & $\begin{array}{c}\text { 断面形状 } \\
(b / D)\end{array}$ & $\begin{array}{c}\text { せん断スパン比 } \\
(M / Q d)\end{array}$ & $\begin{array}{c}\text { 引張鉄筋比 } \\
(\%)\end{array}$ & $\begin{array}{l}\text { 軸力比 } \\
\left(N / b d F_{c}\right)\end{array}$ \\
\hline \multicolumn{2}{|c|}{ 研究対象建物 } & \multirow{4}{*}{1.0} & 3.9 & 0.57 & 0.115 (中柱) \\
\hline \multirow{3}{*}{$\begin{array}{c}\text { 文献 } \\
13), 14\end{array}$} & $\# 51$ & & \multirow{3}{*}{3.0} & \multirow{3}{*}{0.61} & 0.119 \\
\hline & $\# 52$ & & & & \multirow{2}{*}{0.106} \\
\hline & $\# 53$ & & & & \\
\hline
\end{tabular}

* 表中の各記号は以下の通りである。

$b:$ 柱幅 $(\mathrm{mm}), D:$ 柱せい $(\mathrm{mm}), M / Q d: h_{0} / 2 d$ で計算, $h_{0}:$ 柱の内法高さ $(\mathrm{mm}), d:$ 柱の有効せい $(D-50, \mathrm{~mm}), N$ : 軸力 $(\mathrm{N}), F_{c}$ : コンクリート 圧縮強度 $\left(\mathrm{N} / \mathrm{mm}^{2}\right)$

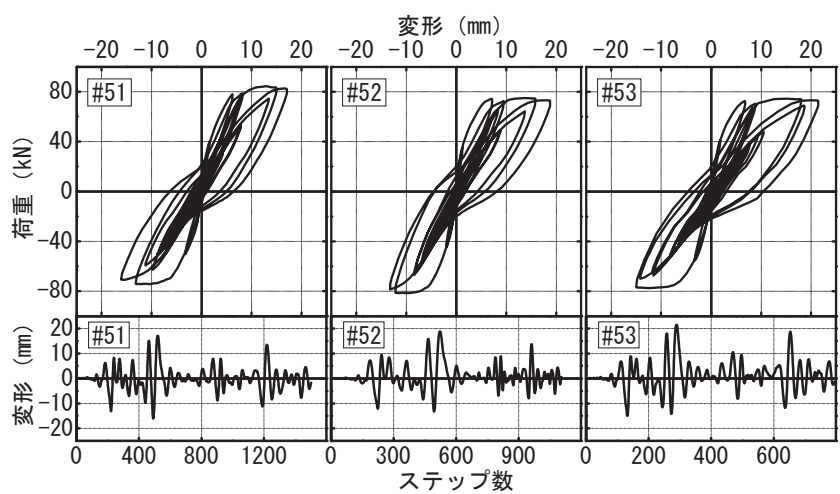

図 9 文献 13)および 14)から抽出した柱の荷重一変形関係および 変形履歴

若干小さいものの，両者は平均的に概ね対応することがわかる。ま た, 変動係数 $\mathrm{COV}$ が 0.13 で, 平均 $\pm 13 \%$ 内にデータの約 $70 \%$ が収 まる結果となっていることから，上記の推定手法が成立するものと 考えた。 


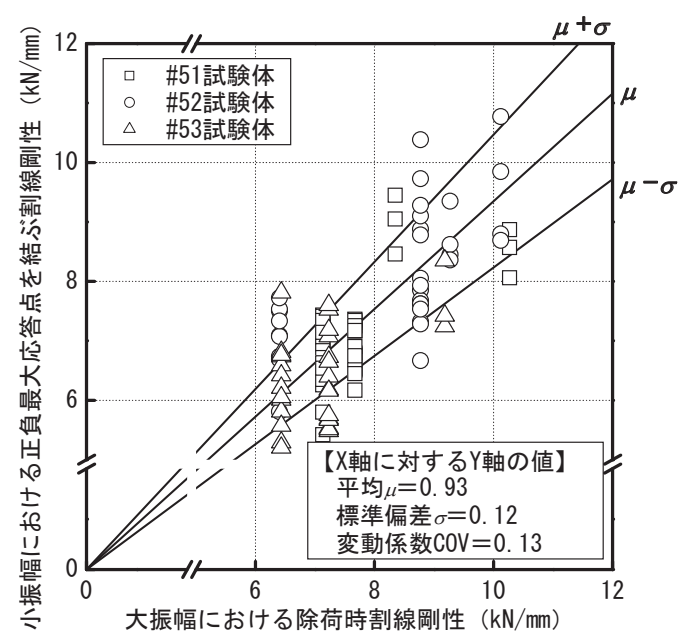

図 10 大振幅と小振幅での割線剛性の比較

\section{（2）推定結果}

図 11 に建物 3 階の除荷時周期と層間変形角の関係を, 同階の層せ 几断力係数と層間変形角の関係と併せて示寸。同図から，3 階の層間 変形角 $1.23 \%$ で本建物の除荷時周期が微動測定で得られた卓越周期 $\left(T_{T}=1.14\right.$ 秒 $)$ に達しており, 当該変形時の 3 階の層せん断力係数は およそ 0.30 であった。

続いて，上記の通り推定された最大変形（図 8 の除荷点の変形）時 の各部材の部材角を損傷度に換算し, 実際の損傷度と比較し, 本推定 手法による再現性を検証する。ここでは，柱の損傷度と部材角の関係 を文献 5)の曲げ柱の場合に準じて評価する。すなわち, 柱の損傷度を 耐震性能低減係数 $\eta$ (損傷度 I $: 0.95$, 損傷度 II : 0.75 , 損傷度 III : 0.50 , 損傷度 IV $: 0.10$, 損傷度 V: 0) に応じて区分する。特に変動軸力に よる外側構面と内側構面の柱の軸力差を考慮するため, 各構面（構面 (1), 構面(2)〜 (4), 構面(5)）を代表する 3 通りの柱を対象に評価する方 針とした。柱の終局性能を文献 9）および文献 11）に基づき表 6 の通 り算定するとともに, これらの終局性能に基づいて損傷度と部材角の 関係を図 12 のように評価した。ここで，本対象建物における柱のせ し断補強筋フックの形状は表 1 に示した通り $90^{\circ}$ であることが現地調 查より明らかになったが, 表 6 のせん断終局強度 $V_{u}$ の算定の際にはせ 儿断補強筋の量あるいは間隔を調節せず実際の数值をそのまま用い た ${ }^{15}$ )。また, 同表の終局部材角 $R_{u}$ は曲げ柱の荷重一変形骨格曲線（図 12）が文献 11）によるせん断終局強度 $V_{u}$ の性能曲線と交差する部材 角として定義した。

図 13 に各柱の 3 階の梁間方向の推定損傷度を実際の損傷度と比較 して示寸。括弧は実際の損傷度を示し, 網掛け部分が実際の損傷度と 適合した柱である。同図より, 本推定手法による柱の損傷度は実被害 を全体的にやや過大評価した。また本推定手法は, 図 11 より層間変 形角 $1.0 \%$ までは除荷時周期の変化が層間変形の変化とおよそ線形な 関係を示しているが, $1.0 \%$ を超過すると周期の変化に対する層間変形 角の変化が大きくなるため, 最大応答変形の推定精度が低下寸る傾向 がある。これは除荷時周期を算定するための除荷時剛性の Takeda model における定義から説明できる。付録 1 に示寸ように，部材変形 に対する除荷時剛性の変化量は降伏点付近を境界に急激に鈍化する 傾向があるため, 推定精度が低下寸ると判断される。従って, 本研究 対象建物の最大経験変形は, 微動測定による卓越周期に基づく変形推

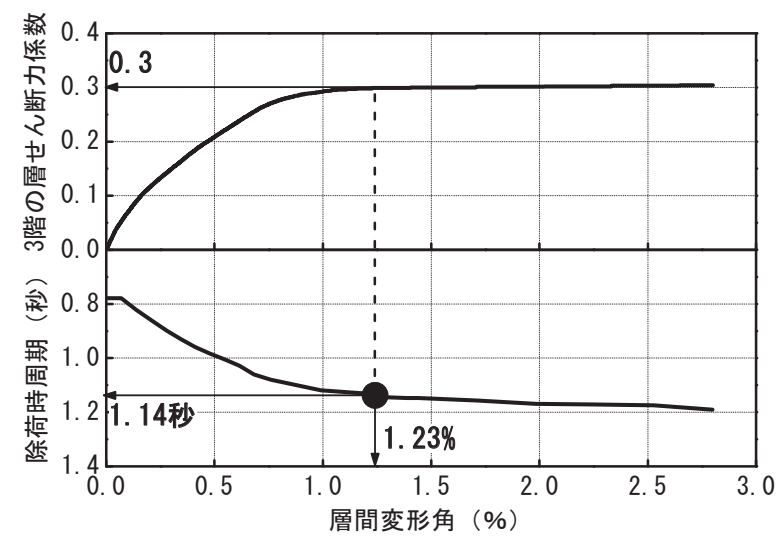

図 113 階の層せん断力一層間変形角関係および除荷時剛性に基づく 周期一層間変形角関係

表 63 階の代表的な柱の終局性能の評価結果

\begin{tabular}{|c|c|c|c|c|c|}
\hline & $\begin{array}{c}\text { 曲げ終局時 } \\
\text { せん断力 } \\
Q_{M U}{ }^{9,111} \\
(k N)\end{array}$ & $\begin{array}{c}\text { せん断 } \\
\text { 終局強度 } \\
V_{u}{ }^{11)} \\
(k N)\end{array}$ & $\begin{array}{c}\text { 降伏 } \\
\text { 部材角 } \\
R_{y}{ }^{9)} \\
(\%)\end{array}$ & $\begin{array}{c}\text { 終局 } \\
\text { 部材角 } \\
R_{u}{ }^{11)} \\
(\%)\end{array}$ & $\begin{array}{c}\text { 終局 } \\
\text { 塑性率 } \\
\mu_{u} \\
\left(R_{u} / R_{y}\right)\end{array}$ \\
\hline 構面 (1) & 134 & \multirow{3}{*}{$\begin{array}{c}242 \\
\left(R_{p}^{*}=0 \text { の時 }\right)\end{array}$} & \multirow{3}{*}{0.67} & 3.4 & 約 5.0 \\
\hline 構面 (2)～(4) & 184 & & & 2.3 & 約 3.4 \\
\hline 構面 (5) & 203 & & & 1.4 & 約 2.1 \\
\hline
\end{tabular}

* 終局限界状態でのヒンジ領域の回転角 ${ }^{11)}$

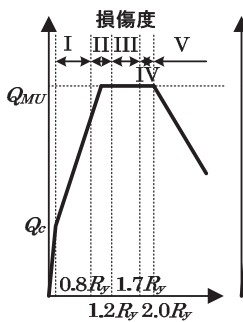

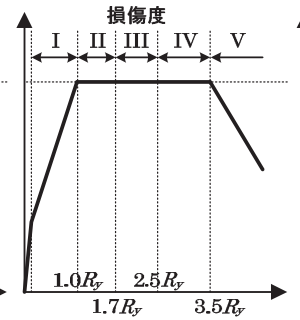

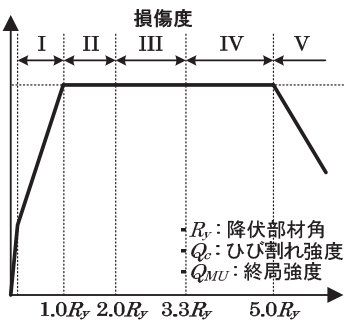
(b) 構面(2) (4)
(c) 構面 (1)
(a) 構面(5)

図 12 代表的な柱の損傷度の定義
(A)
(B) (C)
(D)
(E)
(F) G
(H)

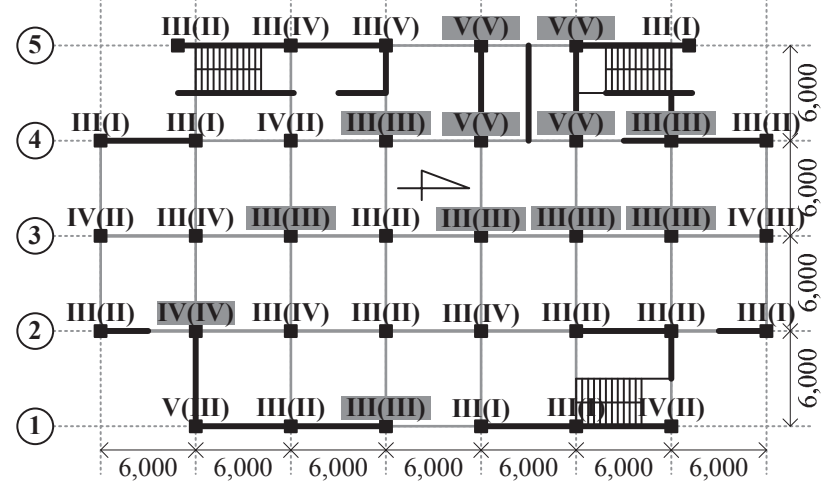

※括弧は実際の損傷度，網掛けは推定結果が適合した柱を示寸。

図 13 卓越周期に基づく推定手法による柱の損傷度と 実際の損傷度の比較

定手法のやや適用範囲外（推定精度が相対的に低い領域）であったと 判断される。 


\section{3 耐震性能残存率 $R^{5)}$ に基づく応答変形推定手法}

上記の検討を踏まえて, 建物の最大応答変形を推定する別法として, 被災度区分判定基準で定義されている耐震性能残存率 $R^{5}$ に着目し, 解析から得られる $R$ 值が被害調查から得られる実際の $R$ 值と一致寸る 時の変形を最大応答変形と見な寸手法を提示する。

(1) 推定フロー

(1) 対象建物に対して静的増分解析を行う（図７の(1)。

(2) 最大被災層に着目して, 柱の損傷度の定義（図 12）に基づき, 各ステップ $j$ で耐震性能残存率 $R_{j}$ を求める。

(3) $R_{j}=R_{T}$ (目標耐震性能残存率, 表 2 の 3 階梁間方向の $R_{T}=54.1 \%$ ) を満足するまで上記の(1)〜(2)を反復計算する。

(4) $R_{j}=R_{T}$ の時の変形を本研究対象建物の最大経験変形と見なす。

\section{(2) 推定結果}

図 14 に建物 3 階の耐震性能残存率 $R$ と層間変形角の関係を, 同階 の層せん断力係数と層間変形角の関係と併せて示す。同図は, 図 11 の除荷時周期の推移を耐震性能残存率 $R$ の推移に置き換えたもので ある。同図から，3 階の層間変形角 $1.05 \%$ で，3 階の $R$ 值が目標 $R$ 值 $\left(R_{T}=54.1 \%\right)$ に達した。この結果は, 前項の微動測定による周期に 基づく推定手法（1.23\%）より若干小さい值である。

前項と同様に, 図 15 では 3 階の層間変形角 $1.05 \%$ におる 3 階の 各部材の損傷度を実損傷度と比較する。同図より, 本推定手法は前項 の推定結果に比べると柱の実被害をより良好に評価している。なお, 柱の実被害は，例えば構面(2)の（）（D)，(E)柱のように，載荷直交方向 に隣接する柱同士でも損傷度が異なるが, 本研究で採用した解析方法 （4.1（1）参照）でこの再現には限界があるものと判断される。しか しながら，当該柱は解析ではいずれも損傷度 III と評価されており， 平均的には実被害と適合する結果と判断される。さらに, 図 14 より, 本推定手法では層間変形角の増大に対寸る耐震性能残存率の低下割 合が $R=0$ に達するまで変形レベルに応じて大きく変動することがわ かった。これは，付録 2 に示すように， $R$ 值を評価するための部材の 耐震性能低減係数 $\eta^{5}$ が不連続であるものの, およそ一定の変形増分に 対して漸減する傾向があるためと判断される。従って, 降伏変形を超 過した程度の被災建物の応答変形は, 微動観測による周期よりも耐震 性能残存率に基づいて評価する方が精度よく推定できると判断され る。

\section{5. まとめ}

本研究では, 2009 年インドネシア・スマトラ島西部地震で被災し た RC 建物および被害概要を整理するとともに，地震動記録がない地 域において, 地震により建物が経験した最大応答変形を推定する手法 として, 微動測定による卓越周期および而震性能残存率に基づいて評 価する 2 手法を提示した。また，各手法を被災建物に適用し，その妥 当性をそれぞれ分析した。本稿の範囲内で得られた知見を以下にまと める。

(1) 研究対象建物で最も被害が大きかった 3 階の梁間方向では耐震性 能残存率 $R$ が $54.1 \%$ で，大破と判定された。

(2) 対象建物の微動測定結果より, 対象建物の 1 次固有周期は, 桁行

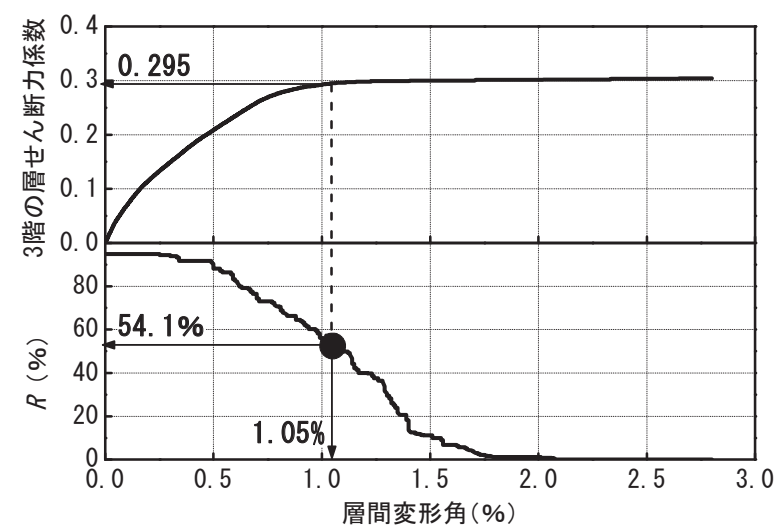

図 143 階の層せん断力一層間変形角関係および而震性能残存率 $R-$ 層間変形角関係
(A) B
(C)
(D)
(E)
(F) (G)
(H)

(5)

(4).

(3)

(2)

(1)

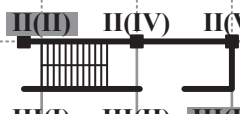

I(V) $V(V) \quad V(V)$ II(I)

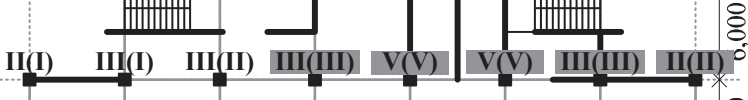

(3)
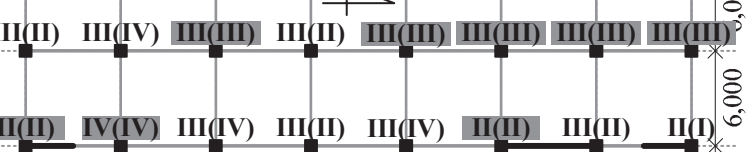

III(III) II(II) II(III) II(I) II

$6,000: 6,000: 6,000$ * $6,000: 6,000: 6,000: 6,000$

※括弧は実際の損傷度，網掛けは推定結果が適合した柱を示す。

図 $15 R$ 值に基づく推定手法による柱の損傷度と

実際の損傷度の比較

(NS) 方向について計測ケース 1 では 0.60 秒, 計測ケース 2 では 0.89 秒で，梁間（EW）方向では両計測ケースともに 1.14 秒であ った。柱の損傷が大きくレンガ壁量も少ない梁間方向の周期が桁 行方向より長いこと，並びに，振動モードの評価結果は現地での 観察結果と整合した。

(3) 対象建物の静的増分解析結果より，3 階の層間変形角が約 $1.0 \%$ を 超過した後に変形が 3 階に集中し, 実際の被害状況と整合寸るこ とを確認した。

(4) 微動測定による固有周期に基づく最大応答变形の推定手法を提案 した。本手法を対象建物に適用した結果，3階の層間変形角 $1.23 \%$ で目標卓越周期に達した。また，この時点では解析より評価され た柱の損傷度が実損傷度をやや過大評価した。これは，典型的な $\mathrm{RC}$ 柱が降伏部材角を超過すると, 部材角の変動に対する除荷時 周期の変動が鈍化し，推定手法の評価精度が低下したためと考え られる。

(5) 耐震性能残存率 $R$ に基づく最大応答変形の推定手法を提案した。 本手法を対象建物に適用した結果，3 階の層間変形角 $1.05 \%$ で目 標 $R$ 值に達した。本推定手法では周期に基づく手法より柱の実被 害を良好に評価した。部材が曲げ降伏変形を超えて応答した建物 の変形推定では，周期よりも耐震性能残存率に基づく推定手法の 精度が高いと判断される。 
今後, 対象建物の地震により経験した最大応答変形の推定精度が相 対的に高かった耐震性能残存率 $R$ に基づく推定手法に対し, 本論文で 未検討である, 静的増分解析における外力分布や部材のモデル化方法 (変動軸力が考慮可能なモデルの導入や梁の非線形特性の考慮など) が推定精度に与える影響について検討を行う予定である。さらに, こ れらの推定手法を地震により損傷を受けた他の $\mathrm{RC}$ 造建物の最大応答 変形推定に適用し, 本稿の結果の一般性についても引き続き分析する 計画である。

\section{謝辞}

研究対象建物の常時微動計測の実施にあたり, 計測機器一式をご提 供頂いた中埜良昭先生（東京大学生産技術研究所教授）に厚く御礼申 し上げます。

\section{参考文献}

1）真田靖士，坂下雅信，黒木正幸，崔琥，細野康代，谷昌典：2009 年インド ネシア・ジャワ島西部地震の調查速報, 建築雑誌, Vol.124, No.1597, 日 本建築学会, pp.64-69, 2009.12

2) 倉本洋, 真田靖士, 崔琥, 坂下雅信, 日比野陽, 壁谷澤寿一, 秋田知芳: 2009 年インドネシア・スマトラ島西部地震の調査速報, 建築雑誌, Vol.125, No.1601, 日本建築学会, pp.55-62, 2010.3

3) 小杉慎司, 境有紀 : 建物被害に対応した地震動強さを損傷を受けた整形な 鉄筋コンクリート造建物から求める方法, 第 12 回日本地震工学シンポジウ ム論文集，pp.146-149，2006.11

4）文野正裕，前田匡樹，長田正至：部材の残余耐震性能に基づいた震災 RC 造建 物の被㷋度評価法に関する研究，コンクリート工学年次論文報告集，Vol.22， No.3, pp.1447-1452, 2000

5）日本建築防災協会: 震災建築物の被災度区分判定基準および復旧技術指針, 2001.9

6) USGS Website : http://www.usgs.gov/ (2010-01-29 参照)

7) EERI Special Earthquake Report - December 2009 (https://www.eeri.org/2009/09)

8）社団法人 日本材料試験協会：シュミットハンマーによる実施コンクリー 卜の圧縮強度判定方法指針，2003

9） 日本建築防災協会 : 既存鉄筋コンクリート造建築物の耐震診断基準・改修 設計指針・同解説，2001

10) T. Takeda, M. A. Sozen and N. M. Nielsen : Reinforced Concrete Response to Simulated Earthquakes, Journal of Structural Division, ASCE, Vol.96, No.ST12, pp.2557-2573, 1970.12

11) 日本建築学会 : 鉄筋コンクリート造建物の勒性保証型耐震設計指針・同解 説, 1999.8

12）日本建築学会 : 鉄筋コンクリート構造計算基淮・同解説，2010

13）神田亮, 白井伸明, 安達洋, 佐藤秎雄 : 鉄筋コンクリート部材の弹塑性応 答性状に関する解析的研究，コンクリート工学年次論文報告集，Vol.10， No.3, pp.313-318, 1988

14) PEER Structural Performance Database (SPD, http://nisee.berkeley.edu/spd/) (2012-10-20 参照)

15) Nguyen Khanh, Swe Zin Win, 真田靖士 : 主筋の継手とせん断補強笳の端部 フックを変動因子とする $\mathrm{RC}$ 柱の 45 度方向載荷実験, コンクリート工学年 次論文集，Vol.34，No.2，pp.169-174，2012.7

\section{付録 1 Takeda model におけるRC 曲げ柱の除荷時剛性の推移}

図 12 (b) の柱を典型的な $\mathrm{RC}$ 柱と見立て, Takeda model ${ }^{10)}$ (除荷剛性低減指 数 $\alpha=0.4 ）$ に置換した場合の除荷時剛性の推移について検討する。付図 1 に図 12(b)の柱の荷重一変形骨格曲線を再掲寸る。同図には本論に加えて設定した評 価仮定 (曲げひび割れ強度 $Q_{C}$ は $Q_{M U} / 3$, ひび割れ発生後の剛性は $0.2 K_{e}$ とする) も掲載した。以上の設定に基づく当該柱の弹性剛性に対する除荷時剛性比一部 材角の関係を付図 2 亿示す。同図より, 弾性剛性に対する除荷時剛性比は降伏 部材角付近から急激に鈍化する傾向が見られることがわかる。

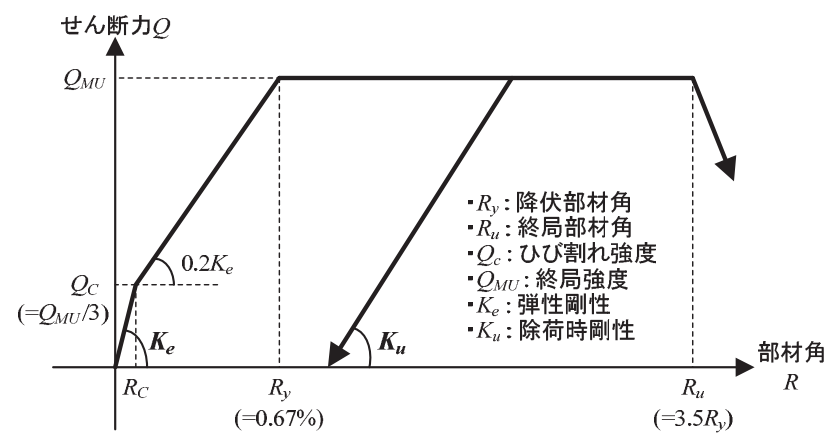

付図 1 典型的な RC 柱（図 12（b)）の性能曲線の設定

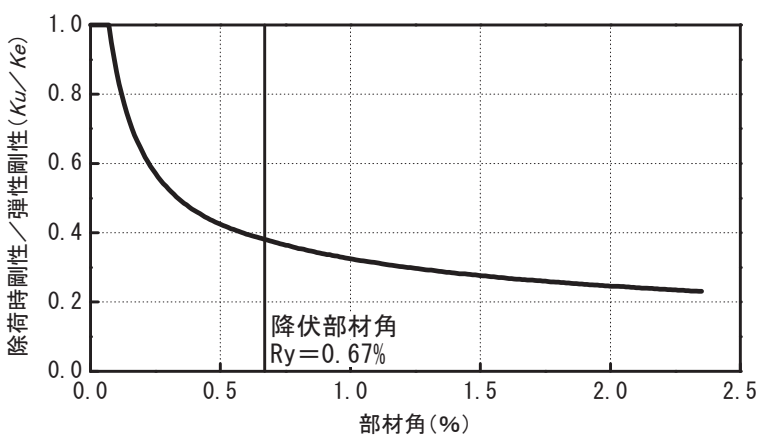

付図 2 弾性剛性に対する除荷時剛性比一部材角の関係

付録 $2 \mathrm{RC}$ 曲げ柱の耐震性能低減係数 $\eta$ の推移

文献 5)より，建物の任意層の耐震性能残存率 $R$ は，当該層を形成寸る鉛直部 材の損傷度に応じた耐震性能低減係数 $\eta$ より計算される。付図 3 に付録 1 と同様 の柱の $\eta$ 值一部材角の関係を示寸。同図より， $\eta$ 值は部材角に応じて一律ではな く不連続に低下寸るものの, 終局変形角まで断続的に漸減する傾向を有してい る。 $R$ 值は, $\eta$ 值が異なる部材群から構成される層に対し評価される数值であり, $\eta$ 值の加重平均值（ただし，本論の対象建物では柱のみについて評価したため平 均值）に相当する。その結果，本論における対象建物 3 階の $R$ 值が図 14 のよう な低下傾向を示したと判断される。

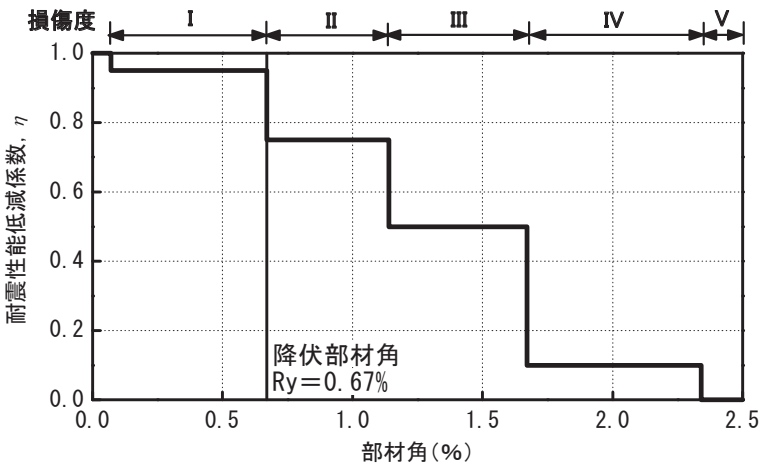

付図 3 而震性能低減係数 $\eta$ 一部材角の関係

（2012年12月27日原稿受理，2013年 7 月 5 日採用決定） 